This document was prepared in conjunction with work accomplished under Contract No. DE-AC09-96SR18500 with the U.S. Department of Energy.

This work was prepared under an agreement with and funded by the U.S. Government. Neither the U. S. Government or its employees, nor any of its contractors, subcontractors or their employees, makes any express or implied: 1 . warranty or assumes any legal liability for the accuracy, completeness, or for the use or results of such use of any information, product, or process disclosed; or 2 . representation that such use or results of such use would not infringe privately owned rights; or 3 . endorsement or recommendation of any specifically identified commercial product, process, or service. Any views and opinions of authors expressed in this work do not necessarily state or reflect those of the United States Government, or its contractors, or subcontractors. 
Key Words:

Tank 804

Plutonium

Organic

Retention: Permanent

\section{Mobilization, Poisoning, and Filtration of F-Canyon Tank 804 Sludge}

Michael R. Poirier

Thomas B. Peters

Samuel D. Fink

May 4, 2006 


\section{LIST OF ACRONYMS}

$\begin{array}{ll}\text { BAB } & \text { branched alkyl benzenes } \\ \text { DIN } & \begin{array}{l}\text { diisopropylnaphthalenes } \\ \text { manganese }\end{array} \\ \text { Mn } & \text { liquid scintillation cocktail } \\ \text { LSC } & \text { plutonium } \\ \text { Pu } & \text { plutonium triphenyltrifluoroacetone scintillation } \\ \text { PuTTA } & \text { analysis } \\ & \text { Resource Conservation and Recovery Act } \\ \text { RCRA } & \text { Site Deactivation and Decommissioning } \\ \text { SDD } & \text { Savannah River National Laboratory } \\ \text { SRNL } & \text { semi-volatile organic analysis } \\ \text { SVOA } & \text { tri-n-butyl phosphate } \\ \text { TBP } & \text { volatile organic analysis } \\ \text { VOA } & \end{array}$




\begin{abstract}
The Savannah River Site (SRS) Deactivation and Decommissioning (SDD) Organization is evaluating options to disposition the F-Canyon 800 series underground tanks (including removal of the sludge heels from these tanks) and requested assistance from Savannah River National Laboratory (SRNL) personnel to develop methods to effectively mobilize the sludge from these tanks (i.e., Tanks 804, 808, and 809).

Because of the high plutonium content in Tank 804 (estimated to be as much as $1500 \mathrm{~g}$ ), SDD needs to add a neutron poison to the sludge. They considered manganese and boron as potential poisons. Because of the large amount of manganese needed and the very slow filtration rate of the sludge/manganese slurry, SDD requested that SRNL investigate the impact of using boron rather than manganese as the poison. SRNL performed a series of experiments to help determine the disposal pathway of the material currently located in Tank 804. The objectives of this work follow.
\end{abstract}

- Determine the mobility of Tank 804 sludge when mixed with $10-15$ parts sodium hydroxide as a function of $\mathrm{pH}$ between 10 and 14 .

- Determine the solubility of boron in sodium hydroxide solution with a free hydroxide concentration between $1 \times 10^{-4}$ and $2.0 \mathrm{M}$.

- Recommend a filter pore size for SDD such that the filtrate contains no visible solids.

- Determine whether a precipitate forms when the filtrate $\mathrm{pH}$ is adjusted to 12,7 , or 2 with nitric acid.

The conclusions from this work follow.

- Filtration of the manganese-containing slurry using a 0.45 micron media occurred very slowly. The results show the filter retained $98 \%$ of the organic species and more than $99 \%$ of the plutonium. However, the rate of filtration is not practical for use in a fullscale process.

- The authors recommend use of $1 \mathrm{M}$ sodium hydroxide, $5 \mathrm{~g} / \mathrm{L}$ boron (from boric acid) solution to mobilize the Tank 804 sludge. Lower boron concentrations may be used if they provide the necessary neutron poisoning, but the effects of reduced boron on the slurry $\mathrm{pH}$ have not been evaluated in this work.

- A 0.45 micron nylon syringe filter removed approximately $90 \%$ of the plutonium and $30 \%$ of the organic species from borated $\mathrm{pH} 14$ caustic slurry. This removal efficiency is less than measured with the manganese-containing slurry.

- The polypropylene cartridge filter pore size demonstrations show removal of $95-97 \%$ of the ${ }^{238} \mathrm{Pu}$ from Tank 804 slurry after diluting $\sim 300: 1$ with a $\mathrm{pH} 14,5 \mathrm{~g} / \mathrm{L}$ boron solution. Based upon these results, the researchers selected a 5 micron Pall Profile ${ }^{\circledR}$ II filter for the filter flux tests.

- Filter flux tests with the 5 micron cartridge filter and Tank 804 sludge diluted 16:1 with borated caustic showed no fouling during the test. However, the feed volume to the filter 
was limited by the available Tank 804 sludge. The filtration reduced the plutonium concentration by $96 \%$.

- Adjustment of the filtrate to nominal $\mathrm{pH} 12$ showed the formation of a small volume second phase. This material contained 14 wt \% TBP, 1 wt \% DIN, and $85 \%$ unknown organic material.

- Adjustment of the filtrate to $\mathrm{pH} 1$ produced a second phase. The solids were filtered and dried, giving an amount of solids equal to $0.7 \mathrm{wt} \%$ of the total solution. The filtered solids contained $\sim 98 \%$ of the ${ }^{238} \mathrm{Pu}$ present in the solution before $\mathrm{pH}$ adjustment. From TIC/TOC measurements, $\sim 81 \%$ of the organic in the original filtrate solution was retained in the solids.

\section{INTRODUCTION}

The SDD Organization is evaluating options to disposition the F-Canyon 800 series underground tanks (including removal of the sludge heels from these tanks) and requested assistance from SRNL personnel to develop methods to effectively mobilize the sludge from these tanks (i.e., Tanks 804, 808, and 809).

Previous work performed at SRNL provided measurements of physical properties for sludge samples from Tanks 804, 808, and 809. Personnel reported values for particle size, solids concentration, density, and settling rate for the sludge. They also provided shear strength measurements and rheological properties from flow curve measurements. ${ }^{1}$

Because of the high plutonium content in Tank 804 (estimated to be $~ 1500 \mathrm{~g}$ ), SDD needs to add a neutron poison to the sludge. They considered manganese and boron as potential poisons. A previously issued report describes the experimental work performed to examine the composition and flow characteristics of the sludge slurry after being mixed with $5.5 \mathrm{wt} \%$ manganese (40:1 ratio of $\mathrm{Mn}: \mathrm{Pu}$ ) and sufficient $8 \mathrm{M}$ caustic to raise the $\mathrm{pH}$ to 7,10 , and $14 .^{2}$ That work showed the sludge was not effectively mobilized at $\mathrm{pH} 7$ and 10, the manganese stayed with the plutonium, and the organic species stayed with the sludge.

Because of the large amount of manganese needed and the very slow filtration rate of the sludge/manganese slurry, SDD requested SRNL to investigate the impact of employing boron rather than manganese as the poison. ${ }^{3}$ The objectives of this work follow.

- Determine the mobility of Tank 804 sludge when mixed with $10-15$ parts sodium hydroxide solution as a function of $\mathrm{pH}$ between 10 and 14 .

- Determine the solubility of boron in sodium hydroxide solution with a free hydroxide concentration between $1 \times 10^{-4}$ and $2.0 \mathrm{M}$.

- Recommend a filter pore size for SDD such that the filtrate contains no visible solids.

- Determine whether a precipitate forms when the filtrate $\mathrm{pH}$ is adjusted to 12,7 , or 2 with nitric acid. 


\section{EXPERIMENTAL}

SDD provided SRNL with a sample of the sludge from Tank 804 in February 2005. SRNL previously analyzed this sample for physical properties and tested the feasibility of using manganese as a neutron poison. ${ }^{1,2}$ The tests reported in this document used the remaining sample. SDD provided a similar sample to the Analytical Development Section for chemical and radionuclide analyses. ${ }^{4,5}$ Those analyses were used to calculate the starting concentrations in the feed slurry for many of the tests conducted.

SRNL personnel performed the following tasks.

- Scoping filtration tests with manganese-containing slurry

- Mobilization tests with Tank 804 sludge blended with sodium hydroxide

- Scoping filtration of Tank 804 sludge/sodium hydroxide slurries and Tank 804 sludge/sodium hydroxide/boric acid slurries

- Boron solubility tests

- Cartridge filter pore size evaluation tests

- Cartridge filter flux tests

- Post filtration $\mathrm{pH}$ adjustment tests

Figure 1 shows the test logic and relationship between the tests conducted. Following completion of the tests to evaluate manganese as a neutron poison, the researchers performed a scouting filtration test to evaluate the feasibility of removing organic constituents from the sludge by filtration. If filtration could remove the organic constituents, the product stream could be sent to the SRS Tank Farm.

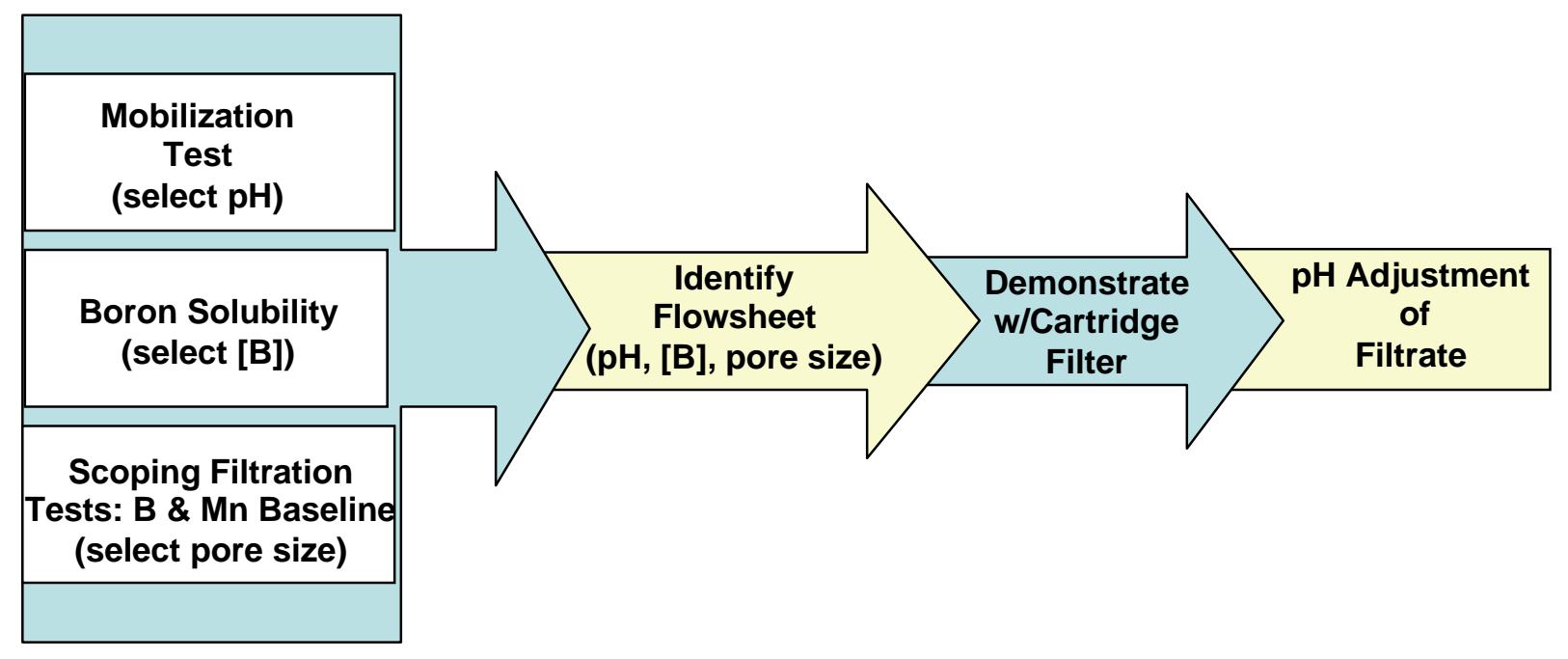

Figure 1. Test Logic

The mobilization tests served to select a $\mathrm{pH}$ (i.e., sodium hydroxide concentration) for the liquid in SDD's flowsheet for mobilizing the sludge. Because SDD was still evaluating the feasibility of using boron as a neutron poison, a boron concentration had not been selected. Also, the soluble boron was not expected to have a significant impact on sludge mobilization. Hence the boron was not added to the sodium hydroxide solution in those tests. 
Researchers performed the boron solubility tests to identify the concentration of boron that could be added to the feed slurry as a function of sodium hydroxide concentration. Boron must remain soluble to be an effective neutron poison.

The scoping filtration tests used a boron/caustic solution mixed with small amount of Tank 804 sludge to evaluate the ability of cartridge filters to remove visible solids, plutonium, and organic constituents.

The data from those tests were used to select the sodium hydroxide concentration, boron concentration, and filter pore size for the flowsheet. The researchers conducted a demonstration with a cartridge filter using these parameters and a higher concentration of Tank 804 sludge ( 16:1 dilution) approximating the planned concentration for operations. Following the cartridge filter demonstration, they performed $\mathrm{pH}$ adjustment tests to evaluate the impact of the $\mathrm{pH}$-adjusted filtrate on H-Canyon.

\section{Scoping Filtration Tests with Manganese-Containing Feed}

Personnel collected approximately $20 \mathrm{~mL}$ of the $\mathrm{pH} 14$ slurry from the manganese addition test performed earlier. ${ }^{2}$ They filtered this slurry through a 0.45 micron nylon cup filter. They submitted the filtrate for plutonium analysis, by plutonium triphenyltrifluoroacetone (PuTTA) and Far Field Gamma, and for organic constituents by volatile organic analysis (VOA) and semi-volatile organic analysis (SVOA). The VOA/SVOA methods provide consistency with previous analyses conducted on the Tank 804 sludge. $^{4}$

\section{Sludge Mobilization Tests}

Personnel added $\sim 2 \mathrm{~g}$ of Tank 804 sludge to centrifuge tubes. They then added $\sim 20 \mathrm{~mL}$ of sodium hydroxide solution to produce nominal $\mathrm{pHs}$ of $10,11,12,13$, and 14 . The nominal $\mathrm{pH}$ values are based on the concentration of sodium hydroxide solution prepared and do not include any interactions between the sludge and the free hydroxide.

Following $\mathrm{NaOH}$ addition, personnel looked for any mobilization that occurred on contact with the $\mathrm{NaOH}$. Technicians mixed the tubes by shaking with the manipulator for 15 minutes, and observed the behavior of the sludge particles. This mixing intensity is less than would be produced by a high pressure water jet or hydrolance, but the test does provide a qualitative indication of the impact of slurry $\mathrm{pH}$ on mobilization of the sludge. They added an additional $10 \mathrm{~mL}$ of sodium hydroxide solution (of sufficient concentration to keep the same $\mathrm{pH}$ ), mixed the solutions for 15 minutes, and observed the sludge behavior. The additional $10 \mathrm{~mL}$ provided a 15:1 dilution and approximated the dilution from the water and $\mathrm{NaOH}$ in the manganese addition tests. Shortly thereafter, they centrifuged the solutions to try to concentrate the solids.

\section{Scoping Filtration Tests with Boron-Containing Feed}

Following centrifugation of the $\mathrm{pH} 14$ sample, personnel placed $\sim 5 \mathrm{~mL}$ of the supernate in a syringe and filtered it through a 1.0 micron filter. Since the filtrate had a dark color, they filtered 
it a second time through a 0.02 micron polyvinylidene difluoride (PVDF) filter. Since this filtrate had a dark color and light could pass through the filtrate, they concluded that the color was due to the filtrate rather than solid particles.

Technicians remixed the remainder of the $\mathrm{pH} 14$ sample and filtered it with a 0.45 micron nylon filter. It filtered without undue effort, also, and produced a filtrate with a dark color.

The researchers prepared a boron-containing slurry in the following manner. Technicians decanted and discarded $10 \mathrm{~mL}$ of supernate from the $\mathrm{pH} 12$ sample ( $30 \mathrm{~mL}$ sample volume) and added $10 \mathrm{~mL}$ of borated sodium hydroxide solution to the remaining sludge slurry. This, in turn, produced a slurry (1 part sludge: 15 parts supernate) with $\mathrm{pH} 14$ and $5 \mathrm{~g} / \mathrm{L}$ boron. They filtered this slurry with a 0.45 micron nylon filter.

\section{Boron Solubility Tests}

Personnel tested the solubility of boron at a range of $\mathrm{pH}$ values. Researchers prepared a matrix of boron (added as boric acid) concentrations $(1,2,3,4$ and $5 \mathrm{~g} / \mathrm{L}$ of boron) in a range of $\mathrm{pH}$ environments ( $\mathrm{pH} \mathrm{10}, 11,12,13,14$, and $2.0 \mathrm{M} \mathrm{NaOH}$ ) giving a total of 30 solubility experiments. Personnel monitored the vials for $\mathrm{pH}$ changes using a $\mathrm{pH}$ meter (Piccolo Plus from Hannah Instruments) or $\mathrm{pH}$ paper, and for the formation of any precipitates.

Personnel performed an additional test in which they placed the $\mathrm{pH} 14,5 \mathrm{~g}$ boron/L sample in a refrigerator at $8{ }^{\circ} \mathrm{C}$ for one week to look for solids formation at reduced temperatures.

\section{Cartridge Filter Pore Size Evaluation Tests}

Personnel prepared 1 liter of $1 \mathrm{M}$ sodium hydroxide, $5 \mathrm{~g} / \mathrm{L}$ boron (added as boric acid) solution. They added approximately $3 \mathrm{~g}$ of Tank 804 sludge to this solution. The ratio of sludge to solution employed in the tests was set at less than the planned process thereby minimizing the amount of sludge used and saving sludge for the filter flux tests. Technicians mixed the slurry and filtered it with a lab-scale cartridge filter unit. They visually observed the filtrate to look for visible solids. Testing used Pall Profile ${ }^{\circledR}$ II filters of absolute pore size 3.0, 5.0, 10.0, and 20.0 micron.

Following each sequential test, technicians collected filtrate samples for photographs, recycled the filtrate to the feed tank, added additional sludge solids as needed, replaced the cartridge filters, and conducted the next test.

\section{Cartridge Filter Flux Tests}

Personnel prepared 1 liter of $1 \mathrm{M}$ sodium hydroxide, $5 \mathrm{~g} / \mathrm{L}$ boron (added as boric acid) solution. They added approximately $60 \mathrm{~g}$ of Tank 804 sludge to this solution. This ratio of sludge to liquid provided a $\sim 16: 1$ dilution (mass basis) of the Tank 804 sludge. The amount added was the $60 \mathrm{~g}$ of the available sludge - rather than the prototypical $100 \mathrm{~g}$ expected for process conditions. Technicians mixed the slurry by shaking and collected feed samples for plutonium analysis. 
Technicians placed a 5.0 micron Pall Profile ${ }^{\circledR}$ II filter in the apparatus. They filtered the slurry through the cartridge filter at a feed rate of $195 \mathrm{~mL} / \mathrm{min}$ and recorded the feed pressure as a function of time.

Technicians collected the filtrate in a low density polyethylene bottle, and several additional samples in glass vials for organic analyses. The filtrate had a dark, burgundy color with no visible solids observed. They diluted a filtrate sample 20:1 (volume basis) with $1 \mathrm{M} \mathrm{NaOH}$ to dilute the color and look for visible solids.

\section{Post Filtration pH Adjustment Tests}

Following the cartridge filter flux tests, personnel performed a two step adjustment of the $\mathrm{pH}$. The first adjustment was to nominal $\mathrm{pH} 12$ to produce a stream with less strenuous transportation restrictions. The second adjustment was from nominal $\mathrm{pH} 12$ to nominal $\mathrm{pH} 7$ to establish neutral conditions for potential disposal as solid waste or via a vendor. To calculate the acid required, the researchers assumed the filtrate contained $1 \mathrm{M} \mathrm{NaOH}$.

Technicians collected $100 \mathrm{~mL}$ of filtrate and adjusted it to $\mathrm{pH} 12$ with $24.7 \mathrm{~mL}$ of $4 \mathrm{M}$ nitric acid. They allowed the slurry to sit over the weekend. Following the weekend, they filtered it through a 0.45 micron nylon cup filter and measured the solids collected on the filter. Following this filtration, the adjusted it to $\mathrm{pH} 7$ with $1.25 \mathrm{~mL}$ of $1 \mathrm{M}$ nitric acid, allowed the solution to sit overnight, and filtered it through a 0.45 micron cup filter.

Technicians performed a second $\mathrm{pH}$ adjustment test designed to mimic the expected $\mathrm{H}$-Canyon $\mathrm{pH}$ adjustment. They added $18.26 \mathrm{~mL}$ of $2 \mathrm{M}$ nitric acid to a Teflon ${ }^{\mathrm{TM}}$ bottle. They then added $3.41 \mathrm{~mL}$ of deionized water and mixed the bottle contents. This amount of acid was based on the measured free hydroxide in the filtrate (not available at the time of the first $\mathrm{pH}$ adjustment) and the relative volumes of acid and filtrate that $\mathrm{H}$-Canyon personnel plan to mix in the $\mathrm{pH}$ adjustment process. To the bottle, technicians added $100 \mathrm{~mL}$ of Tank 804 filtrate over 10 minutes. They mixed the bottle continuously for four days and observed the contents for any precipitation.

\section{RESULTS}

\section{Scoping Filtration Tests with Manganese-Containing Feed}

Filtration of the manganese-containing slurry occurred very slowly. Personnel collected $10 \mathrm{~mL}$ of filtrate in approximately 8 hours. Even though the filtration was conducted at a small-scale, the rate was too slow for filtration of this slurry to be practical at a larger scale.

Table 1 shows the plutonium and organic analyses of the feed ${ }^{4,5}$ and filtrate. The results show removal of $98 \%$ of the organic species and more than $99 \%$ of the plutonium by the filter. 
Table 1. Filtration of pH 14 Tank 804 Sludge and Manganese Slurry

\begin{tabular}{|c|c|c|c|}
\hline $\begin{array}{l}\text { Species } \\
\text { Plutonium }\end{array}$ & $\begin{array}{c}\text { Feed (calc.) } \\
\underline{\operatorname{dpm} / \mathbf{g}}\end{array}$ & $\begin{array}{c}\text { Filtrate (meas.) } \\
\underline{\mathrm{dpm} / \mathrm{g}}\end{array}$ & $\begin{array}{c}\text { Removed } \\
\underline{\%}\end{array}$ \\
\hline $\mathrm{Pu}-238$ & $2.0 \mathrm{E}+08$ & $1.43 \mathrm{E}+05$ & 99.9 \\
\hline $\mathrm{Pu}-239$ & $1.1 \mathrm{E}+07$ & $9.52 \mathrm{E}+03$ & 99.9 \\
\hline Organic species & $\underline{\mathrm{mg} / \mathrm{kg}}$ & $\underline{\mathrm{mg} / \mathrm{kg}}$ & $\underline{\%}$ \\
\hline$\overline{\mathrm{TBP}}$ & 2950 & 82.9 & 97.2 \\
\hline tetradecane & 492 & 6.48 & 98.7 \\
\hline tridecane & 200 & 3.52 & 98.2 \\
\hline Flon & 4.5 & 0.762 & 83.1 \\
\hline DIN & 377 & $<0.238$ & $>99.9$ \\
\hline $\mathrm{BAB}$ & 50 & $<0.238$ & $>99.5$ \\
\hline pentadecane & 46 & $<0.238$ & $>99.5$ \\
\hline dodecane & 19 & 0.343 & 98.2 \\
\hline nonanenitrile & 0.78 & 0.238 & 69.5 \\
\hline octanenitrile & 0.6 & $<0.238$ & $>60.3$ \\
\hline 1-nonene & 15 & $<0.238$ & $>98.4$ \\
\hline 4-nonene, 5-butyl- & 13 & $<0.238$ & $>98.2$ \\
\hline 4-undecene, 6-methyl- & 13 & $<0.238$ & $>98.2$ \\
\hline dioctyl phthalates & 235 & $<0.238$ & $>99.9$ \\
\hline phenol, 4-1(1-methyl-1-phenylethyl) & 39 & $<0.238$ & $>99.4$ \\
\hline unidentified & 19 & $<0.238$ & $>98.7$ \\
\hline $\begin{array}{l}\text { ethanol, 2-[4-(1,1- } \\
\text { dimethylethyl)phenoxyl- }\end{array}$ & 18 & $<0.238$ & $>98.7$ \\
\hline dibutyl 3 hydroxybutyl phosphate & 17 & $<0.238$ & $>98.6$ \\
\hline 1-butanol & ND & 5.71 & \\
\hline 2-ethyl-1-hexanol & ND & 0.381 & \\
\hline organic species & 4510 & 100 & 97.8 \\
\hline
\end{tabular}

$\mathrm{ND}=$ none detected

* Feed concentration calculated from analysis of the Tank 804 sludge $^{4,5}$ and the amount of caustic mixed with the sludge.

\section{Sludge Mobilization Tests}

Mixing the sludge with $\mathrm{pH} 10,11$, and 12 sodium hydroxide solution did not adequately mobilize, or suspend, the solids. Most of the sludge remained stuck to the walls of the tube (see Figure 2). The $\mathrm{pH} 10$ and 11 supernate appeared clear. An additional $10 \mathrm{~mL}$ (50 vol \%) of the appropriate concentration of $\mathrm{NaOH}$ added to these samples did not improve sludge mobilization. 
The pH 12 supernate remained cloudy, although most of the sludge remained stuck to the walls. Additional $\mathrm{NaOH}$ appeared to mobilize a little more sludge, but most of the sludge remained stuck to the tube wall.

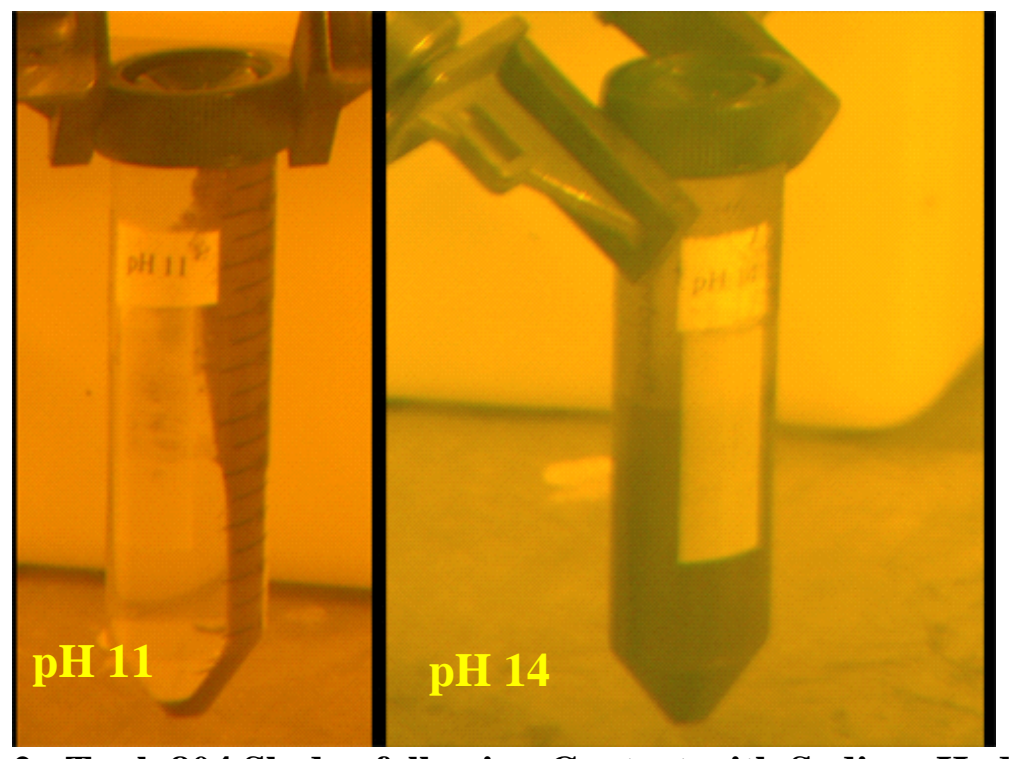

Figure 2. Tank 804 Sludge following Contact with Sodium Hydroxide

The pH 13 slurry was partially mobilized, and the supernate had a dark brown color. Addition of more $\mathrm{NaOH}$ solution $(10 \mathrm{~mL})$ mobilized more sludge, but some of the sludge remained stuck to the tube wall.

The $\mathrm{pH} 14$ slurry showed significant mobilization of sludge after the addition of $20 \mathrm{~mL}$ of $1 \mathrm{M}$ sodium hydroxide. The additional sodium hydroxide $(10 \mathrm{~mL})$ seemed to mobilize almost all of the remaining sludge that was not mobilized by the first caustic addition. The supernate had a dark brown color.

Because the $\mathrm{pH}$ 10, 11, and 12 slurries did not mobilize the sludge, the researchers did not analyze the solids concentrated by centrifugation. The solids in the $\mathrm{pH} 13$ and 14 samples appeared to settle slowly during centrifugation. After 3.5 hours, the sample showed some solids settling at the bottom of the tube. The supernate still appeared dark, but subsequent analysis showed the darkness was due to color rather than solid particles.

Based on these results, the authors recommend that SDD employ $1 \mathrm{M}$ sodium hydroxide solution $(\sim \mathrm{pH} 14)$ to mobilize the Tank 804 sludge.

\section{Scoping Filtration Tests with Boron-Containing Feed}

Personnel filtered the supernate from the $\mathrm{pH} 14$ sample described above (not containing added boron) through a 1 micron nylon syringe filter. The sample filtered very quickly, but the filtrate had a burgundy color (see Figure 3). Technicians further filtered the filtrate through a 0.02 micron PVDF syringe filter. This filtrate also had a burgundy color. Attempts to shine a light through the filtrate showed partial transparency with the dark hue due to color rather than the 
presence of solid particles. They did not analyze this filtrate for radionuclides or chemical constituents.

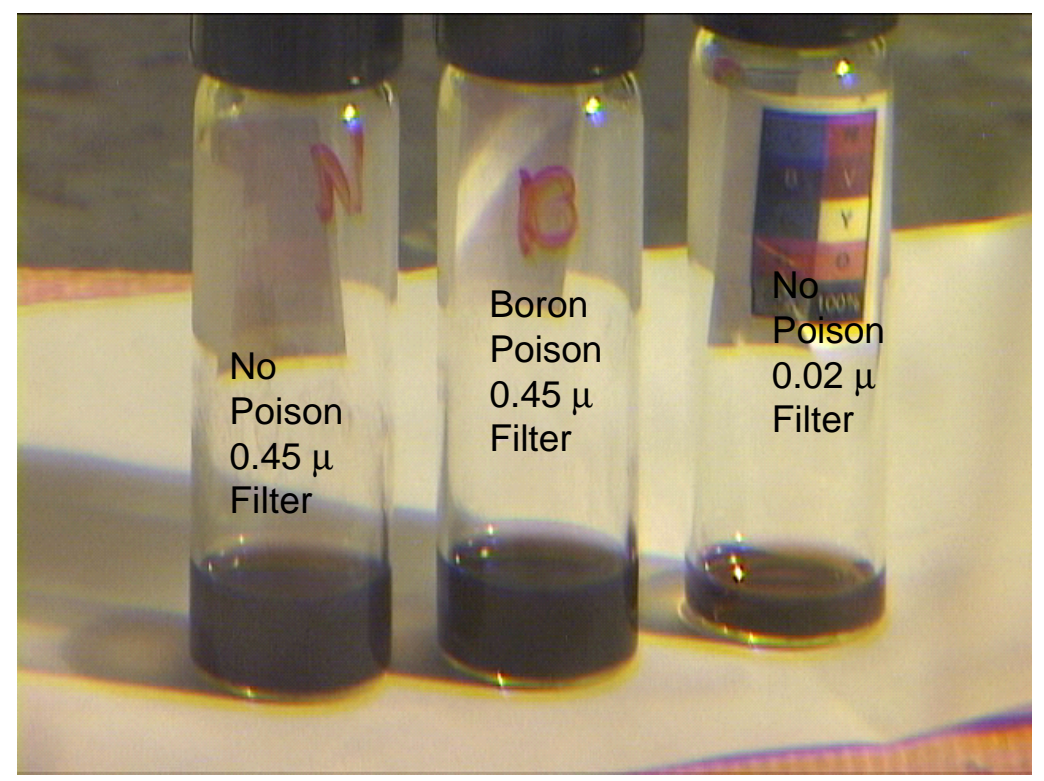

Figure 3. Tank 804 Filtrate

Following this test, personnel remixed the $\mathrm{pH} 14$ sample (not containing added boron) and filtered it through a 0.45 micron nylon syringe filter. The material filtered quickly and the filtrate had a burgundy color. The researchers did not analyze this filtrate for radionuclides or chemical constituents.

Personnel prepared a $5 \mathrm{~g}$ boron/L, $1 \mathrm{M} \mathrm{NaOH}$ sample in the following manner. Technicians removed $10 \mathrm{~mL}$ of supernate from the $\mathrm{pH} 11$ sample $(30 \mathrm{~mL}$ volume $)$ and combined the remaining sludge slurry with $10 \mathrm{~mL}$ of $3 \mathrm{M}$ sodium hydroxide/15 $\mathrm{g} / \mathrm{L}$ boron solution. This addition to the $\mathrm{pH} 11$ sample raised the free hydroxide to $1.0 \mathrm{M}$ and the boron content to $5 \mathrm{~g} / \mathrm{L}$. They filtered this material through a 0.45 micron nylon syringe filter. The material filtered easily and the filtrate had a burgundy color. They submitted this filtrate sample for plutonium and organic analysis.

Table 2 shows the plutonium and organic analyses of the filtrate, as well as the calculated concentrations in the feed slurry. The filter removed approximately $90 \%$ of the plutonium and $30 \%$ of the organic species. This removal efficiency is less than measured with the manganesecontaining slurry. 
Rev. 0

Table 2. Filtration of pH 14 Tank 804 Sludge and Boron Slurry

Species
Plutonium
${ }^{238} \mathrm{Pu}$
${ }^{239} \mathrm{Pu}$

\section{Organic species}

TBP

tetradecane

tridecane

flon

DIN

$\mathrm{BAB}$

pentadecane

antioxidant

1,1-biphenyl, 3-nitro

dodecane

1-tridecanol

1-pentadecene

hexadecene

cyclotetradecane

1-octadecanol

Ethanol, 2-[4-(1,1-

dimethylethyl)phenoxyl-

p-tert-amyl phenoxy ethanol

n-decanoic acid

3,5-dimethoxy-4-hydroxycinnamic acid

1,1-biphenyl,3-nitro

phenol,o-(alpha., alpha.-

dimethylbenzyl)-

decanenitrile

benzoic acid,4-(phenylmethyl)-

triphenylene, 1,2,3,4,5,6,7,8,9,10,11,12-

dodecahydro

undecanoic acid

Organic species

\begin{tabular}{|c|c|c|}
\hline $\begin{array}{c}\text { Feed (calc.) }{ }^{*} \\
\underline{\mathrm{dpm} / \mathrm{g}}\end{array}$ & $\begin{array}{c}\text { Filtrate (meas.) } \\
\qquad \underline{\mathbf{d p m} / \mathbf{g}}\end{array}$ & $\begin{array}{c}\text { Removed } \\
\underline{\%}\end{array}$ \\
\hline $1.88 \mathrm{E}+08$ & $1.8 \mathrm{E}+07$ & $90.4 \%$ \\
\hline $1.15 \mathrm{E}+07$ & $1.1 \mathrm{E}+06$ & $90.4 \%$ \\
\hline$\underline{\mathrm{mg} / \mathrm{kg}}$ & $\underline{\mathrm{mg} / \mathrm{kg}}$ & \\
\hline 2297 & 1900 & $17 \%$ \\
\hline 907 & 480 & $47 \%$ \\
\hline 459 & 170 & $63 \%$ \\
\hline 308 & $<20$ & $>94 \%$ \\
\hline 236 & 270 & $0 \%$ \\
\hline 157 & $<20$ & $>87 \%$ \\
\hline 85 & $<20$ & $>76 \%$ \\
\hline 85 & $<20$ & $>76 \%$ \\
\hline 79 & $<20$ & $>75 \%$ \\
\hline 30 & $<20$ & $>34 \%$ \\
\hline 17 & $<20$ & $0 \%$ \\
\hline 16 & $<20$ & $0 \%$ \\
\hline 15 & $<20$ & $0 \%$ \\
\hline 15 & $<20$ & $0 \%$ \\
\hline 11 & $<20$ & $0 \%$ \\
\hline ND & 47 & \\
\hline ND & 64 & \\
\hline ND & 41 & \\
\hline ND & 39 & \\
\hline ND & 36 & \\
\hline ND & 32 & \\
\hline ND & 30 & \\
\hline ND & 30 & \\
\hline ND & 26 & \\
\hline ND & 25 & \\
\hline 4717 & 3190 & $32 \%$ \\
\hline
\end{tabular}

$\mathrm{ND}=$ none detected

* Feed concentration calculated from analysis of the Tank 804 sludge $e^{4,5}$ and the amount of borated caustic mixed with the sludge. 


\section{Boron Solubility Tests}

To use boron as a neutron poison, it must have adequate solubility properties - if only a minimal amount of boron remains soluble it will not provide adequate neutron capture in solution.

Researchers prepared a series of 30 vials, each containing $10 \mathrm{~mL}$ of solution containing boric

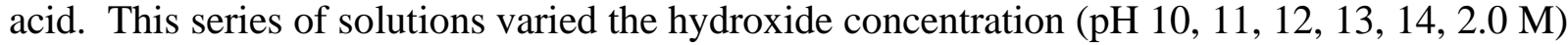
and boron concentration $(1,2,3,4$, and $5 \mathrm{~g} / \mathrm{L})$. After preparation, personnel measured the $\mathrm{pH}$ using a pH probe (Piccolo Plus from Hannah Instruments) or $\mathrm{pH}$ paper for each vial and inspected them for the formation of any solids or precipitate.

Measurement of the sealed vials over a week indicated that the $\mathrm{pH} 10,11,12$, and 13 solutions drifted lower in $\mathrm{pH}$ over time. The drift is possibly due to continued consumption of small amounts of hydroxide as the borate is transformed into different boron oxides (metborate, etc). The $\mathrm{pH} 14$ and $2.0 \mathrm{M}$ solutions stayed at $\mathrm{pH} 14$ according to the $\mathrm{pH}$ paper indicator. As a confirmation of the added boron in solution, they submitted five samples of the solutions to measure the boron in solution (Table 3).

Table 3. Boron in Solution

\begin{tabular}{|c|c|c|}
\hline Sample ID & $\begin{array}{c}\text { Calculated Boron } \\
\text { Conc. }(\mathbf{m g} / \mathbf{L})\end{array}$ & $\begin{array}{c}\text { Measured Boron } \\
\text { Conc. } \mathbf{( m g / L )}\end{array}$ \\
\hline A & 4000 & 4450 \\
\hline B & 4000 & 4540 \\
\hline C & 5000 & 5660 \\
\hline D & 1000 & 1230 \\
\hline E & 0 & 18.2 \\
\hline
\end{tabular}

The analytical and instrumental uncertainty in the measurement is $20 \%$, indicating the sample results acceptably match the predicted values. Sample E had no added boric acid and the low measured concentration likely came from boron leaching from the glass sample vials.

Over a period of several weeks, personnel visually monitored each of the 30 glass sample vials for the formation of any solids. In no case did any visible solids or precipitate form in any of the vials. As a final check to insure that lower temperatures would not induce precipitation, they stored the $5 \mathrm{~g} / \mathrm{L}$ boron, $\mathrm{pH} 14$ vial in a refrigerator at $8^{\circ} \mathrm{C}$ for 1 week. The colder temperatures did not cause the formation of any solids.

\section{Cartridge Filter Pore Size Evaluation Tests}

Figure 4 shows the filtrate from the cartridge filter tests. The feed has a dark color due to organic constituents and particles. The 20 micron filtrate shows particulate solids and color. The 10 micron filtrate shows a slight haze, but no visible solids. The haze is likely due to fine particulate solids. The 3 micron and 5 micron filtrates show color, but no visible solids. 
Table 4 shows the plutonium results from the 3,5, and 10 micron polypropylene filter tests. The results show $95-97 \%$ of the ${ }^{238} \mathrm{Pu}$ removed by the filter. Based upon these results and review with SDD personnel, researchers selected a 5.0 micron Pall Profile ${ }^{\circledR}$ II filter for the filter flux tests.

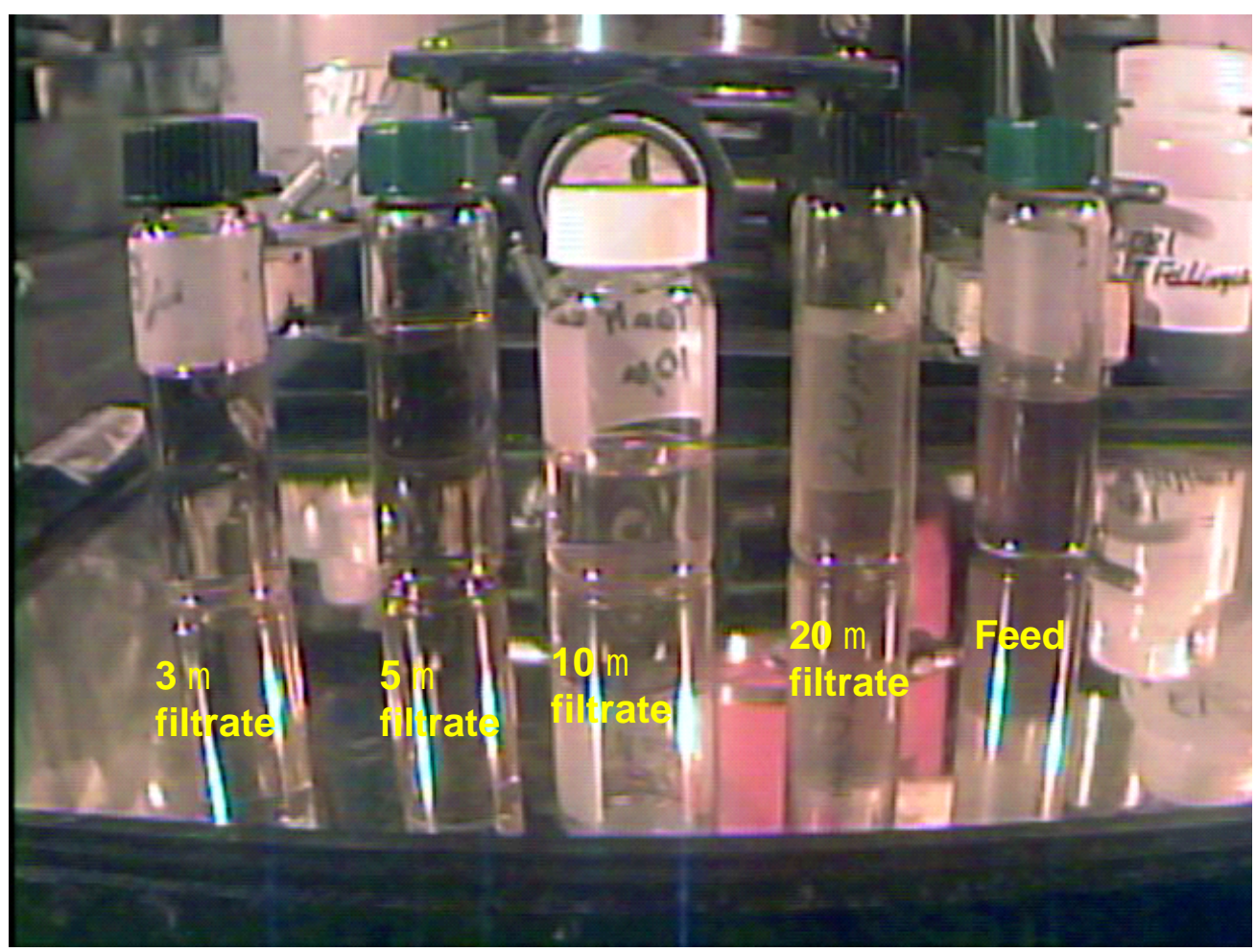

Figure 4. Cartridge Filter Filtrate

Table 4. Filtrate Plutonium Analyses

$\begin{array}{cccc}\text { Pore Size } & \text { Feed }{ }^{238} \mathbf{P u}(\mathbf{d p m} / \mathbf{g}) & \text { Filtrate }{ }^{\mathbf{2 3 8}} \mathbf{P u}(\mathbf{d p m} / \mathbf{g}) & \mathbf{\%} \text { Removed } \\ 3 \text { micron } & 7.4 \mathrm{E}+06 & 2.6 \mathrm{E}+05 & 97 \% \\ 5 \text { micron } & 1.2 \mathrm{E}+07 & 6.7 \mathrm{E}+05 & 94 \% \\ 10 \text { micron } & 7.4 \mathrm{E}+06 & 2.6 \mathrm{E}+05 & 97 \%\end{array}$

* Feed concentration calculated from analysis of the Tank 804 sludge ${ }^{4,5}$ and the amount of borated caustic mixed with the sludge.

\section{Cartridge Filter Flux Tests}

Prior to starting the filter flux tests, personnel passed the feed slurry from the filter pore size tests through the cartridge filter unit to ensure proper sealing of the filter in the housing. The filtrate from this check contained no visible solids allowing the full test to proceed. 
Technicians processed the feed slurry through the filter using a peristaltic pump at a flow rate of $195 \mathrm{~mL} / \mathrm{min}$. During the entire test, the feed pressure remained less than $1 \mathrm{psig}$. This low pressure indicates that no significant filter fouling occurred.

The filtrate (see Figure 5) had a dark color making observation of visible solids difficult. Personnel diluted the filtrate 20:1 (volume basis) with sodium hydroxide. They observed no visible solids.

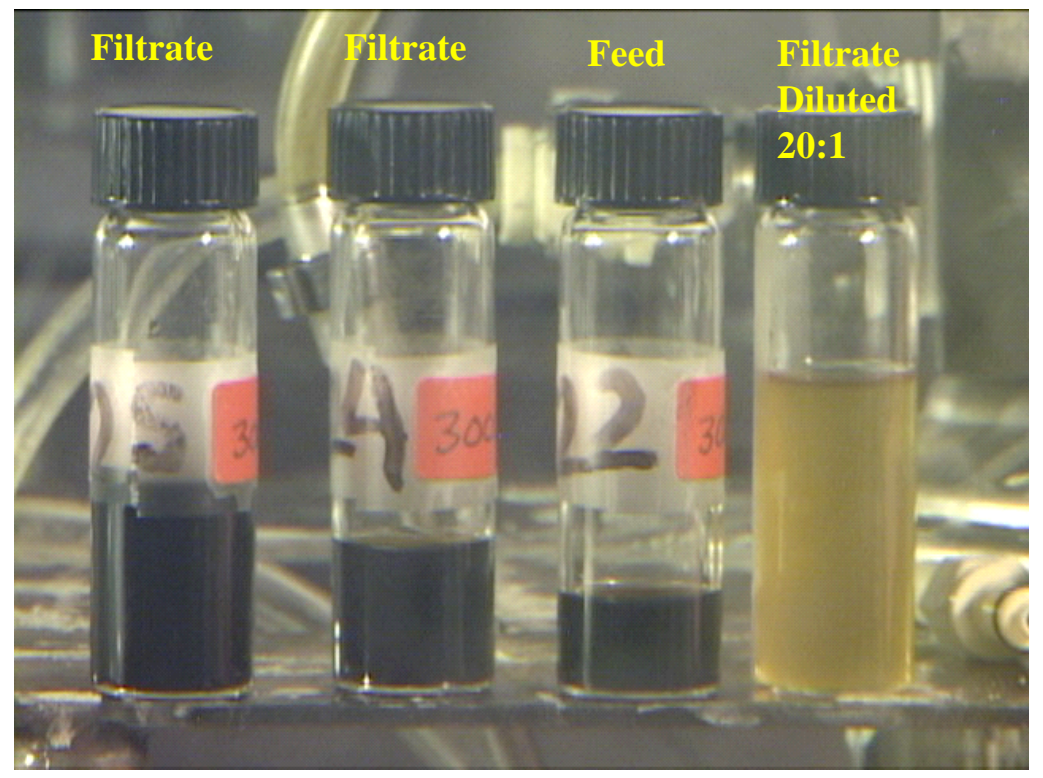

Figure 5. Filter Feed, Filtrate, and Filtrate Diluted 20:1

Following filtration, technicians weighed the cartridge filter and recorded an increase of $57.59 \mathrm{~g}$ from the wet solids. Following drying in an oven, personnel measured the added weight as $9.51 \mathrm{~g}$ of dry solids.

Personnel collected $493 \mathrm{~g}$ of filtrate and passed it through a 0.45 micron nylon cup filter. Following filtration, technicians dried the filter in an oven. Following drying, the weight increased by $0.75 \mathrm{~g}$. The weight increase could be from solid particles or from a second organic phase.

Technicians collected the filtrate and submitted samples for analyses. The analyses performed on the filtrate included measurements for radionuclides, organic and inorganic compounds, and physical properties. The sludge values are calculated from the measured values in previous work ${ }^{4,5}$ and divided by the 16.2:1 dilution factor. The removal percentage for all analytes is calculated from comparing the calculated Tank 804 sludge slurry to filtrate (=1-(filtrate/sludge)).

Table 5 contains the plutonium measurements for both the diluted Tank 804 sludge and the filtrate. The data show good agreement between the calculated plutonium in the filter feed (based on the original Tank 804 sludge plutonium analysis and the dilution factor) and the measured plutonium in the filter feed. Because of this good agreement, the authors calculated the expected concentration of other species in the filter feed (Tables 6-8). 
Table 5. Plutonium Measurements

\begin{tabular}{|l|c|c|c|c|}
\hline \multicolumn{5}{|c|}{ Plutonium Results } \\
\hline $\begin{array}{l}\text { Species } \\
\text { Plutonium (analytical uncertainty) }\end{array}$ & $\begin{array}{c}\mathbf{8 0 4} \text { Sludge } \\
\text { (calculated) } \\
\text { (pm/g 14 feed }\end{array}$ & $\begin{array}{c}\text { pHeasured) } \\
\text { (menote } \\
\text { dpm/g }\end{array}$ & $\begin{array}{c}\text { Filtrate } \\
\text { (measured) } \\
\mathbf{d p m} / \mathbf{g}\end{array}$ & $\begin{array}{c}\text { Removed } \\
\text { (calculated) } \\
\mathbf{\%}\end{array}$ \\
\hline${ }^{238} \mathrm{Pu}(\sim 10 \%)$ & $1.85 \mathrm{E}+08$ & $1.88 \mathrm{E}+08$ & $7.16 \mathrm{E}+06$ & 96.1 \\
\hline${ }^{239 / 240} \mathrm{Pu}(\sim 10 \%)$ & $9.88 \mathrm{E}+06$ & $1.15 \mathrm{E}+07$ & $3.45 \mathrm{E}+05$ & 96.5 \\
\hline
\end{tabular}

Both the ${ }^{238} \mathrm{Pu}$ and ${ }^{239 / 40} \mathrm{Pu}$ measurements indicate a $>96 \%$ removal.

* Feed concentration calculated from analysis of the Tank 804 sludge ${ }^{4,5}$ and the amount of borated caustic mixed with the sludge.

The organic content of the Tank 804 sludge was measured previously ${ }^{4}$ using volatile organic analysis (VOA) and semi-volatile organic analysis (SVOA). Table 6 reports these values (after accounting for the dilution factor) as well as the measurements of the filtrate from the 5 micron cartridge filter demonstration.

Table 6. Organic Compound Measurements

\begin{tabular}{|c|c|c|c|}
\hline \multicolumn{4}{|c|}{ Organic Results } \\
\hline $\begin{array}{l}\text { Species } \\
\text { Organic species (analytical uncertainty) }\end{array}$ & $\begin{array}{c}\text { Tank } 804 \text { Sludge } \\
\text { (calculated) }^{*} \\
\text { mg/kg } \\
\end{array}$ & $\begin{array}{c}\text { Filtrate } \\
\text { (measured) } \\
\text { mg/kg } \\
\end{array}$ & $\begin{array}{c}\text { Removed } \\
\text { (calculated) } \\
\% \\
\end{array}$ \\
\hline TBP (10\%) & 2,350 & 2,670 & -13.6 \\
\hline DIN (10\%) & 241 & 162 & 32.8 \\
\hline tetradecane $(10 \%)$ & 926 & 33.3 & 96.4 \\
\hline tridecane $(10 \%)$ & 469 & 13.3 & 97.2 \\
\hline 1, 1'-biphenyl, 3-nitro (10\%) & 80.2 & 11.4 & 85.8 \\
\hline $\mathrm{BAB}(10 \%)$ & 160 & $<10$ & $>93.8$ \\
\hline Flon $(10 \%)$ & 315 & $<10$ & $>96.8$ \\
\hline pentadecane $(10 \%)$ & 86.4 & $<10$ & $>88.4$ \\
\hline dodecane $(10 \%)$ & 30.9 & $<10$ & $>67.6$ \\
\hline Total SVOA Organic & 4,660 & 2,890 & 38.0 \\
\hline \multicolumn{4}{|l|}{ TIC/TOC (analytical uncertainty) } \\
\hline Total Organic Carbon (10\%) & NA & 13,900 & - \\
\hline Total Inorganic Carbon (10\%) & NA & 224 & - \\
\hline
\end{tabular}

$\mathrm{NA}=$ Not Available - measurement not applicable or not performed

* Feed concentration calculated from analysis of the Tank 804 sludge ${ }^{4,5}$ and the amount of borated caustic mixed with the sludge. 
The negative value for TBP removal is presumed to mean that all of the TBP passes through the filter. The difference in the feed and filtrate values falls within the $95 \%$ confidence uncertainty of the analytical method. Other species had an appreciable removal and the overall organic removal was $38 \%$.

The total inorganic carbon/total organic carbon (TIC/TOC) results differ significantly from the VOA/SVOA results. This discrepancy most likely indicates that there is a large portion of organic material $(\sim 83 \%)$ that exists in the filtrate that is not identified by VOA/SVOA. As this material does not show up under these methods, it must be a relatively low vapor-pressure specie or species.

In an attempt to close the missing balance, SRNL did an explicit VOA scan for butanol in the filtrate, which is a decomposition product of TBP. They measured a butanol concentration of $340 \mathrm{mg} / \mathrm{L}$, which does not come close to closing the mass balance. Butanol, with an LFL of 1.4 volume $\%$, is the only flammable material found so far.

Besides plutonium, the researchers measured various radionuclides in the filtrate (Table 7), and calculated the concentrations in the feed slurry. 
Table 7. Radionlucide Measurements

\begin{tabular}{|c|c|c|c|}
\hline \multicolumn{4}{|c|}{ Selected Radionuclide Results } \\
\hline $\begin{array}{l}\text { Species } \\
\text { Selected Radionuclides } \\
\quad \text { (analytical uncertainty) }\end{array}$ & $\begin{array}{c}\text { Tank 804 Sludge } \\
\begin{array}{c}\text { (calculated) } \\
\text { dpm } / g\end{array} \\
\end{array}$ & $\begin{array}{c}\text { Filtrate } \\
\text { (measured) } \\
\text { dpm/g }\end{array}$ & $\begin{array}{c}\text { Removed } \\
\text { (calculated) } \\
\% \\
\end{array}$ \\
\hline${ }^{137} \mathrm{Cs}(\sim 2 \%)$ & $5.43 \mathrm{E}+04^{1}$ & $2.88 \mathrm{E}+04$ & 47.0 \\
\hline${ }^{241} \mathrm{Am}(\sim 2 \%)$ & $6.88 \mathrm{E}+05^{1}$ & $1.17 \mathrm{E}+04$ & 98.3 \\
\hline LSC Total Alpha (10\%) & NA & $1.19 \mathrm{E}+07$ & - \\
\hline LSC Total Beta (10\%) & $3.69 \mathrm{E}+7$ & $<1.42 \mathrm{E}+06$ & $>96.2$ \\
\hline Gross Alpha (10\%) & $6.85 \mathrm{E}+07$ & $7.80 \mathrm{E}+06$ & 88.6 \\
\hline${ }^{90} \mathrm{Sr}(10 \%)$ & $3.33 \mathrm{E}+05$ & $<2.25 \mathrm{E}+03$ & $>99.3$ \\
\hline${ }^{233} \mathrm{U}(20 \%)$ & $<172$ & $<1020$ & - \\
\hline${ }^{234} \mathrm{U}(20 \%)$ & $1.13 \mathrm{E}+03$ & $<661$ & $>41.5$ \\
\hline${ }^{235} \mathrm{U}(20 \%)$ & 2.35 & 0.334 & 85.8 \\
\hline${ }^{236} \mathrm{U}(20 \%)$ & 18.0 & $<6.84$ & $>62.0$ \\
\hline${ }^{238} \mathrm{U}(20 \%)$ & 50.8 & 8.84 & 82.6 \\
\hline${ }^{237} \mathrm{~Np}(20 \%)$ & $2.20 \mathrm{E}+03$ & 463 & 79.0 \\
\hline${ }^{232} \operatorname{Th}(20 \%)$ & 5.01 & 0.046 & 99.1 \\
\hline${ }^{246} \mathrm{Cm}(20 \%)$ & $2.07^{6}$ & $<8.00 \mathrm{E}-03^{6}$ & $>99.6$ \\
\hline${ }^{99} \mathrm{Tc}$ (LLD) & $<2.70 \mathrm{E}+04$ & $<5.09 \mathrm{E}+03$ & - \\
\hline${ }^{60} \mathrm{Co}(\sim 2 \%)$ & $<71.6$ & 4.50 & - \\
\hline \multicolumn{4}{|l|}{$\underline{\text { Am/Cm (analytical uncertainty) }}$} \\
\hline${ }^{241} \mathrm{Am}(\sim 3 \%)$ & $6.88 \mathrm{E}+05^{1}$ & $2.65 \mathrm{E}+04$ & 96.1 \\
\hline${ }^{243} \mathrm{Am}(\sim 9 \%)$ & $1.20 \mathrm{E}+02$ & $<3.44 \mathrm{E}+03$ & \\
\hline${ }^{242} \mathrm{Cm}(\sim 38 \%)$ & 3.75 & $<3.21 \mathrm{E}+01$ & \\
\hline${ }^{244} \mathrm{Cm}(\sim 8 \%)$ & $1.20 \mathrm{E}+04$ & $<4.63 \mathrm{E}+01$ & $>99.6$ \\
\hline \multicolumn{4}{|c|}{ Tritium Results } \\
\hline $\begin{array}{l}\text { Species } \\
\text { Selected Radionuclides } \\
\quad \text { (analytical uncertainty) }\end{array}$ & $\begin{array}{c}\text { Tank 804 Sludge } \\
\begin{array}{c}\text { (calculated) }^{*} \\
\mu \mathrm{Ci} / \mathrm{g}\end{array} \\
\end{array}$ & $\begin{array}{c}\text { Filtrate } \\
\text { (measured) } \\
\mu \mathrm{Ci} / \mathrm{g} \\
\end{array}$ & $\begin{array}{c}\text { Removed } \\
\text { (calculated) } \\
\% \\
\end{array}$ \\
\hline${ }^{3} \mathrm{H}$ (LLD) & $<1.57 \mathrm{E}-04$ & $<9.81 \mathrm{E}-05$ & - \\
\hline
\end{tabular}

LLD $=$ Lower Level Detection limit

NA $=$ Not Available - measurement not applicable or not performed

$\mathrm{TBD}=\mathrm{To}$ Be Determined - value not yet received

* Feed concentration calculated from analysis of the Tank 804 sludge ${ }^{4,5}$ and the amount of borated caustic mixed with the sludge.

\footnotetext{
${ }^{1}$ This value was directly measured instead of calculated
} 
The removal efficiency for the gross alpha agrees within $95 \%$ confidence with the value for plutonium when considering the analytical accuracy.

Researchers used inductively coupled plasma emission spectroscopy (ICPES), atomic absorbtion (AA) and ion chromatography (IC) to measure the non-radioactive inorganic constituents of the diluted Tank 804 sludge and its filtrate (Table 8). Elements in bold are RCRA elements.

Table 8. Measured Inorganic Components

\begin{tabular}{|c|c|c|c|}
\hline \multicolumn{4}{|c|}{ Inorganic Species Results } \\
\hline $\begin{array}{l}\text { Species } \\
\text { Inorganic species (analytical uncertainty) }\end{array}$ & $\begin{array}{c}\text { Tank 804 Sludge } \\
\text { (calculated) }^{*} \\
\mu \mathrm{g} / \mathrm{g}\end{array}$ & $\begin{array}{c}\text { Filtrate } \\
\text { (measured) } \\
\mu \mathrm{g} / \mathrm{g}\end{array}$ & $\begin{array}{c}\text { Removed } \\
\text { (calculated) } \\
\%\end{array}$ \\
\hline $\mathrm{B}(10 \%)$ & 1.12 & 4600 & \\
\hline As $(10 \%)$ & $<0.0784$ & $<0.0262$ & \\
\hline Se $(10 \%)$ & $<0.157$ & $<0.0524$ & \\
\hline $\operatorname{Ag}(10 \%)$ & 21.2 & 2.29 & 89.3 \\
\hline $\mathbf{B a}(10 \%)$ & 206 & $<1.62$ & $>99.2$ \\
\hline Cd $(10 \%)$ & $<0.184$ & $<1.93$ & \\
\hline $\mathrm{Cr}(10 \%)$ & 7.22 & $<3.09$ & $>57.2$ \\
\hline $\mathrm{Fe}(10 \%)$ & 58.3 & 3.20 & 94.5 \\
\hline $\mathrm{Mn}(10 \%)$ & 0.612 & $<0.264$ & $>56.8$ \\
\hline $\mathrm{Na}(10 \%)$ & 12.7 & 19600 & \\
\hline $\mathrm{NH}_{4}^{+}(10 \%)$ & NA & $<95.2$ & \\
\hline $\mathbf{P b}(10 \%)$ & 8.52 & $<47.2$ & \\
\hline Hg $(10 \%)$ & 396 & 11.6 & 97.1 \\
\hline $\mathrm{F}^{-}(10 \%)$ & NA & 365 & \\
\hline $\mathrm{Cl}^{-}(10 \%)$ & NA & 418 & \\
\hline $\mathrm{Br}^{-}(10 \%)$ & NA & 10.5 & \\
\hline $\mathrm{HCO}_{2}^{2-}(10 \%)$ & NA & 256 & \\
\hline $\mathrm{C}_{2} \mathrm{O}_{4}{ }^{2-}(10 \%)$ & NA & 246 & \\
\hline $\mathrm{NO}_{2}^{-}(10 \%)$ & NA & 243 & \\
\hline $\mathrm{NO}_{3}^{-}(10 \%)$ & NA & 132 & \\
\hline $\mathrm{PO}_{4}{ }^{3-}(10 \%)$ & 354 & 88.6 & 74.9 \\
\hline $\mathrm{SO}_{4}{ }^{2-}(10 \%)$ & 354 & 89.5 & 74.7 \\
\hline
\end{tabular}

NA = Not Available - measurement not applicable or not performed

$\mathrm{TBD}=\mathrm{To}$ Be Determined - value not yet received

* Feed concentration calculated from analysis of the Tank 804 sludge ${ }^{4,5}$ and the amount of borated caustic mixed with the sludge.

The boron and sodium results show a great increase due to the addition of the borated caustic solution that was used to dilute the Tank 804 sludge. 
The phosphate and sulfate values for the diluted Tank 804 sludge are determined indirectly from the ICP-ES method as opposed to the more typical ion chromatography. The reported value assumes all measured phosphorous is present as phosphate and all measured sulfur is present as sulfate.

Finally, we measured some of the physical properties of the diluted Tank 804 sludge and its filtrate (Table 9).

Table 9. Selected Physical Properties

\begin{tabular}{|l|c|c|}
\hline \multicolumn{3}{|c|}{ Miscellaneous Measurements Results } \\
\hline Measurement (analytical uncertainty) & $\begin{array}{c}\text { Tank 804 Sludge } \\
\text { (measured) }\end{array}$ & $\begin{array}{c}\text { Filtrate } \\
\text { (measured) }\end{array}$ \\
\hline Weight \% Insoluble Solids (10\%) & NA & $0.72 \%$ \\
\hline Total Dissolved Solids & NA & $7.72 \%$ \\
\hline Free Hydroxide (5\%) & NA & $0.322 \mathrm{M}$ \\
\hline Density, g/mL (10\%) & $1.17^{2}$ & 1.05 \\
\hline
\end{tabular}

NA $=$ Not Available - measurement not applicable or not performed

This density measurement for the original Tank 804 sludge is much lower than expected based on the density and insoluble solids concentration data for Tanks 808 and 809 (1.52 and $1.42 \mathrm{~g} / \mathrm{mL}$, respectively $)^{1}$. The likely difference is the large organic content of this sludge.

\section{Post Filtration pH Adjustment Tests}

After sitting over the weekend, the nominal pH 12 slurry had a second phase on the bottom of the low density polyethylene bottle. This phase did not readily re-suspend by shaking. A SVOA analysis of the second phase indicated the material contained $14 \mathrm{wt} \% \mathrm{TBP}, 1 \mathrm{wt} \% \mathrm{DIN}$, and $85 \mathrm{wt} \%$ unknown. This ratio of TBP to unidentified material is roughly consistent with the ratio between TBP and total organic carbon measured in the filtrate.

Personnel re-filtered the bulk contents of the bottle using a 0.45 micron cup filter. The material filtered slowly. Following filtration, the filter had a dark color. The color could be due to either inorganic particulates or a separate organic phase. The second phase remaining on the bottle bottom weighed $2.26 \mathrm{~g}$ (wet). The second phase collected on the filter weighed $0.34 \mathrm{~g}$ following oven drying to constant weight at $50^{\circ} \mathrm{C}$.

After sitting overnight, the nominal pH 7 slurry (pH 5.4 measured) did not show a second phase. Technicians poured that material into a 0.45 micron cup filter and applied vacuum to the filter. The material filtered slowly. Following filtration, the filter had no change in color. Following oven drying to constant weight at $50{ }^{\circ} \mathrm{C}$, the filter weight had increased $0.30 \mathrm{~g}$.

\footnotetext{
${ }^{2}$ This is for the undiluted sludge.
} 
Finally, $100 \mathrm{~mL}$ of the $\mathrm{pH} 14$ filtrate was adjusted to take it to nominal $\mathrm{pH} 2$, using $2.0 \mathrm{M}$ nitric acid. The amount of nitric acid required was calculated from the measured free hydroxide The addition generated a red-orange solution with no evidence of solids. Using a $\mathrm{pH}$ probe (Piccolo Plus from Hannah Instruments), the solution $\mathrm{pH}$ measured as 9.9. This large gap is possibly due to consumption of the acid by the unknown organics present in the solution. Additional pH adjustment was performed and described in Table 10. A small quantity of solids was briefly produced at $\mathrm{pH} 7$, followed by almost immediate dissolution of the solids. Once the $\mathrm{pH}$ was less than 4 , significant solids formed.

Table 10. pH adjustment of Tank 804 Filtrate to $\mathrm{pH} 1$

$\begin{array}{llll}\text { Volume }(\mathrm{mL}) & \text { Acid } & \text { Measured pH } & \text { Observations } \\ 100 & 18.26 \mathrm{~mL} \mathrm{2} \mathrm{M} \mathrm{HNO3} & 9.9 & \text { No solids } \\ 38 & 3.2 \mathrm{~mL} 0.001 \mathrm{M} \mathrm{HNO3} & 9.9 & \text { No solids } \\ 39 & 0.6 \mathrm{~mL} \mathrm{5} \mathrm{M} \mathrm{HNO3} & 9.3 & \text { No solids } \\ 38 & 0.6 \mathrm{~mL} \mathrm{5} \mathrm{M} \mathrm{HNO3} & 8.3 & \text { No solids } \\ 37 & 0.6 \mathrm{~mL} \mathrm{5} \mathrm{M} \mathrm{HNO3} & 7.1 & \text { A few solids } \\ 36 & 0.6 \mathrm{~mL} \mathrm{5} \mathrm{M} \mathrm{HNO3} & 3.3 & \text { Solids } \\ 35 & 0.6 \mathrm{~mL} \mathrm{5} \mathrm{M} \mathrm{HNO3} & 1.1 & \text { Solids }\end{array}$

Personnel filtered the $\mathrm{pH}$ adjusted material, collected the solid phase, and dried it. The solids concentration measured $4.5 \mathrm{wt} \%$ wet and $0.7 \mathrm{wt} \%$ dry. They collected the filtrate and submitted it for plutonium and organic analyses. The ${ }^{238} \mathrm{Pu}$ in the filtrate following $\mathrm{pH}$ adjustment measured $1.56 \mathrm{E}+05 \mathrm{dpm} / \mathrm{g}$ vs $7.16 \mathrm{E}+06 \mathrm{dpm} / \mathrm{g}$ prior to $\mathrm{pH}$ adjustment and filtration. This result indicates most of the ${ }^{238} \mathrm{Pu}(\sim 98 \%)$ is with the solid phase. The total organic carbon in the filtrate measured $2670 \mathrm{mg} / \mathrm{kg}$ versus $13,600 \mathrm{mg} / \mathrm{kg}$ prior to $\mathrm{pH}$ adjustment and filtration, indicating that $\sim 81 \%$ of the organic material is retained by the filter. Performing a mass balance, one calculates the solids contain $0.55 \mathrm{~g}$ of total organic carbon $(0.38-0.73 \mathrm{~g}$ at $95 \%$ confidence). This calculated value is greater than the measured solids concentration by drying $(0.345 \mathrm{~g})$, but the results are close when considering the uncertainty of the measurements and calculation.

\section{CONCLUSIONS}

The conclusions from this work follow.

- Filtration of the manganese-containing slurry using a 0.45 micron media occurred very slowly. The results show the filter retained $98 \%$ of the organic species and more than $99 \%$ of the plutonium. However, the rate of filtration is not practical for use in a fullscale process.

- The authors recommend use of $1 \mathrm{M}$ sodium hydroxide, $5 \mathrm{~g} / \mathrm{L}$ boron (from boric acid) solution to mobilize the Tank 804 sludge. Lower boron concentrations may be used if they provide the necessary neutron poisoning, but the effects of reduced boron on the slurry $\mathrm{pH}$ have not been evaluated in this work. 
- A 0.45 micron nylon syringe filter removed approximately $90 \%$ of the plutonium and $30 \%$ of the organic species from borated $\mathrm{pH} 14$ caustic slurry. This removal efficiency is less than measured with the manganese-containing slurry.

- The polypropylene cartridge filter pore size demonstrations show removal of $95-97 \%$ of the ${ }^{238} \mathrm{Pu}$ from Tank 804 slurry after diluting $\sim 300: 1$ with a $\mathrm{pH} 14,5 \mathrm{~g} / \mathrm{L}$ boron solution. Based upon these results, the researchers selected a 5 micron Pall Profile ${ }^{\circledR}$ II filter for the filter flux tests.

- Filter flux tests with the 5 micron cartridge filter and Tank 804 sludge diluted 16:1 with borated caustic showed no fouling during the test. However, the feed volume to the filter was limited by the available Tank 804 sludge. The filtration reduced the plutonium concentration by $96 \%$.

- Adjustment of the filtrate to nominal pH 12 showed the formation of a small volume second phase. This material contained $14 \mathrm{wt} \% \mathrm{TBP}, 1 \mathrm{wt} \% \mathrm{DIN}$, and $85 \%$ unknown organic material.

- Adjustment of the filtrate to $\mathrm{pH} 1$ produced a second phase. The solids were filtered and dried, giving an amount of solids equal to $0.7 \mathrm{wt} \%$ of the total solution. The filtered solids contained $\sim 98 \%$ of the ${ }^{238} \mathrm{Pu}$ present in the solution before $\mathrm{pH}$ adjustment. From TIC/TOC measurements, $\sim 81 \%$ of the organic in the original filtrate solution was retained in the solids. 


\section{REFERENCES}

1. M. R. Poirier, E. K. Hansen, P. R. Burket, and S. D. Fink, "F-Canyon Sludge Physical Properties", WSRC-TR-2005-00381, Rev. 0, August 22, 2005.

2. M. R. Poirier, M. E. Stallings, P. R. Burket, and S. D. Fink, "Composition and Flow Behavior of F-Canyon Tank 804 Sludge Following Manganese Addition and $\mathrm{pH}$ Adjustment", WSRC-TR-2005-00540, November 30, 2005.

3. R. A. Eubanks, "Determine Effectiveness of Removing Sludge from Tank 804 by $\mathrm{NaOH}$ Washing/Mixing and Filtration B Poisoned Mixture", January 25, 2006.

4. L. M. Chandler, A. R. Jurgensen, and D. M. Missimer, "Tanks 804, 808, and 809 Radiochemistry and Organic Data Compilation and Independent Technical Review", SRNL-ADS-2005-00463, July 29, 2005.

5. R. A. Sigg, "Tank 804 Sludge Radionuclides Results and Independent Technical Review", SRNL-ADS-2005-00485, July 25, 2005.

6. T. B. Peters, D. T. Hobbs, D. P. DiPrete, C. C. DiPrete, S. D. Fink, "Final Report on the Demonstration of Disposal of Americium and Curium Legacy Material Through the High Level Waste System", WSRC-TR-2002-00029, January 16, 2002. 
APPROVAL

Author:

M. R. Poirier, Process Chemistry Science

T. B. Peters, Process Chemistry Science

Design Check:

Customer:

Management:

J. $\ell$. Griffin, CKemical Science \& Technology Manager
G. J. Zadhmann III, Chief Engineer

F Canyon Complex Deactivation

S. D. Fink, Process Chemistry Science Manager

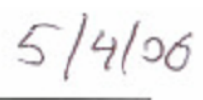

Date

$5 / 4 / 06$

Date

$\frac{5 / 5 / 06}{\text { Date }}$

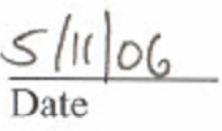

$5 / 5 / 2006$

Date

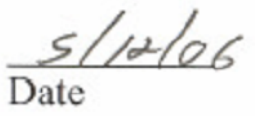

